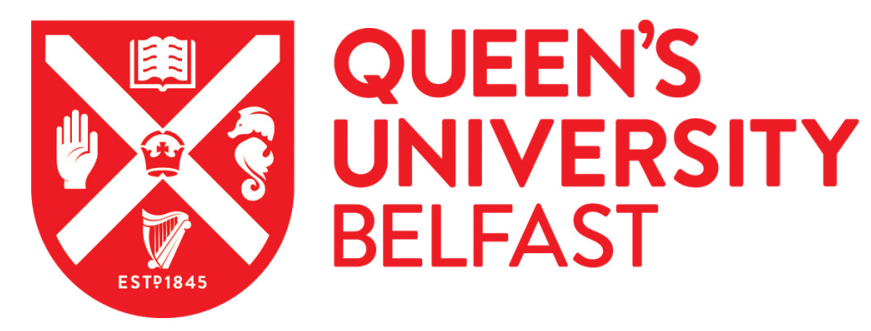

\title{
Accounting change in the Scottish and Westminster central governments: a study of voice and legitimation
}

Hyndman, N., \& Liguori, M. (2019). Accounting change in the Scottish and Westminster central governments: a study of voice and legitimation. Financial Accountability \& Management, 35(4), 390-412.

https://doi.org/10.1111/faam.12219

\section{Published in:}

Financial Accountability \& Management

\section{Document Version:}

Peer reviewed version

Queen's University Belfast - Research Portal:

Link to publication record in Queen's University Belfast Research Portal

\section{Publisher rights}

(C) 2019 John Wiley \& Sons Ltd.

This work is made available online in accordance with the publisher's policies. Please refer to any applicable terms of use of the publisher.

\section{General rights}

Copyright for the publications made accessible via the Queen's University Belfast Research Portal is retained by the author(s) and / or other copyright owners and it is a condition of accessing these publications that users recognise and abide by the legal requirements associated with these rights.

Take down policy

The Research Portal is Queen's institutional repository that provides access to Queen's research output. Every effort has been made to ensure that content in the Research Portal does not infringe any person's rights, or applicable UK laws. If you discover content in the Research Portal that you believe breaches copyright or violates any law, please contact openaccess@qub.ac.uk. 
Accepted Paper Financial Accountability \& Management (Accepted September 2019)

Accounting change in the Scottish and Westminster central governments: a study of voice and legitimation

Authors’ Details:

Noel Hyndman and Mariannuziata Liguori

Queen's Management School

Queen's University Belfast

Riddel Hall

185 Stranmillis Road

Belfast BT9 5EE

Northern Ireland, UK

Tel: +44 (0)2890974933 / +44 (0)289097 4491

E-mail: n.hyndman@qub.ac.uk/m.liguori@qub.ac.uk 


\title{
ACCOUNTING CHANGE IN THE SCOTTISH AND WESTMINSTER CENTRAL GOVERNMENTS: A STUDY OF VOICE AND LEGITIMATION
}

\begin{abstract}
Organisational voice processes are crucial during change. These will affect actors' individual understanding of change and the way in which change is perceived and legitimated generally. Looking at accounting changes at two government levels (Westminster and Scotland), this paper explores relationships between organisational voice processes during change (exploring these in terms of horizontal/vertical and promotive/prohibitive dimensions) and legitimation strategies subsequently used by the actors involved. In Westminster, where promotive vertical voicing was particularly identifiable, interviewees predominantly legitimated change through rationalisation strategies. In Scotland, where prohibitive, horizontal voice processes were more evident, authorisation strategies tended to prevail. However, regardless of the content and direction of voice, ultimately, the vast majority of key accounting changes in both Westminster and Scotland were supported (legitimated) by actors.
\end{abstract}

Keywords: accounting change, voice, legitimation, central government, managerialism

\section{INTRODUCTION}

Previous studies on the public sector in general, and on accounting in particular, have investigated the implementation of change at the organisational level, while much less attention has been paid to understanding the role individuals have in shaping it (Contrafatto and Burns, 2013; Hyndman and Liguori, 2017). We claim that language and organisational dialogues have an important function in shaping the process of change at both the organisational and individual levels. Actors' participation and voice, in particular, can capture crucial aspects of information transmission and exchange between the organisational members involved in and affected by change (Lines, 2005). This will, in turn, affect the actors' understanding of change and the way they talk about and legitimate it. This study brings together two dimensions of the voice process (direction and content), in order to highlight possible links in the way organisational actors understand and legitimate change. In particular, looking at the introduction of new financial accounting, budgeting and performance-management techniques (collectively referred to as 'accounting' for convenience) in two cases, representing different government levels (Westminster and the devolved administration of Scotlandi), this paper aims to explore whether a relationship exists between organisational voice processes (as perceived by the main organisational actors) that take place during change and legitimation strategies used by the actors involved in the change itself. Using a comparative approach, the study focuses on the arguments, voices and legitimation strategies that may be used by the organisational members to support or criticise these changes. Rather than investigate a change implementation gap (as many studies have done in the past), the paper considers the talk and decision stages during change, as suggested by Brunsson (1989a, 1989b, see also Brunsson and Olsen, 1993).

Drawing on management literature seldom used in accounting studies, this paper brings together perceptions of how voice is exerted during processes of accounting change and individual legitimations and accounts of such changes. The research thus contributes by shedding more light on the individual processes of legitimation that may lead to different organisational results. Moreover, while previous studies have focused on either the content of voice or its direction separately (Liang et al., 2012), this paper looks at these dimensions together, investigating a case of change in a calculative practice (accounting change). The paper is organised as follows: the next 
section presents the literature on organisational voice processes and legitimation strategies; subsequently, the methods are discussed, followed by the empirical context of the research and the results in Westminster and Scotland. Finally, a discussion of the main findings of the research is presented, followed by conclusions. Included with the conclusions, is a discussion of further research avenues which outlines possible aspects of a research agenda for those interested in adding to knowledge in the much under-researched area of voice processes and public-sector accounting change.

\section{VOICE PROCESSES AND LEGITIMATION STRATEGIES}

Change generates uncertainty, which is often responded to by organisational actors through discussions and possibly justification (or expressions of concern) for any proposed new course of action or structure. The relationship between the channels and processes through which organisational actors voice their opinions during change and the arguments they subsequently use to give sense to it has been little investigated in the past, especially in relation to accounting. This paper aims to contribute to fill this gap. The following subsections review the main literature and findings in relation to organisational voice processes and legitimation strategies during (accounting) change.

\subsection{Voice and Accounting Change}

During change, voicing processes have been shown to be crucial, for better or worse, within organisations (Detert et al., 2013). Many scholars have argued that expressing voice can have positive effects, in particular with respect to engagement in activities, focusing on the reduction of errors, improving organisational routines and producing innovations (Shapiro, 1993; Edmondson, 2003). Voice ${ }^{\text {ii }}$ represents a transmission of information between two parties, from a speaker to a target, perhaps with the intention of making things better via proactive behaviour (although other, more negative, motives are also possible). This contrasts with the extreme reaction of responding to current situations, or proposed changes, with silent loyalty or exit (Hirschman, 1970). This study specifically focuses on how voice can be exerted during change, rather than on the reasons and effects of those who chose to exit. Voice is hard to punish for its absence and it is difficult to evaluate (Van Dyne et al., 1995). As such, it can be a risky behaviour and have negative consequences for the speaker ${ }^{\mathrm{iii}}$. However, voice has great potential value to those who receive it, thanks to the opportunity it provides to: spot possible problems before they occur; benefit from the collective knowledge of others; and pursue suggested improvements. Voice often involves challenging the status quo by suggesting changes to current practice, or adjusting proposed future changes that have been announced but have yet to be implemented. In addition, it can, and often does, emanate from individuals with limited formal decision-making and resource-allocation power to effect change (Detert et al., 2013).

On the basis of previous literature, two main dimensions of the voice process can be identified: its direction and its content. Detert et al. (2013) have emphasised the importance of understanding the structure of voice, and from whom and to whom it flows. However, current theory has not specified the potential differences between voice directed laterally to peers, and upward to one's own boss (or to leaders elsewhere in the organisation) (Liu et al., 2010). Voice directed laterally to co-workers to evaluate consensus on an issue, to vent, or to receive social support can have a different, even harmful, effect on unit performance when compared to speaking up to a direct boss. Previous research, indeed, has suggested that voice to individuals up the organisational hierarchy (either direct bosses or managers at a higher level) may potentially generate more visible change for the unit and the whole organisation (Brinsfield et al., 2009). Previous findings indicate a reduced level of filtering or concern about the quality of a given idea prior to speaking to coworkers; which contrasts with how employees reflect on what they say when speaking with people 
with a higher position (and more power) within an organisation (Mesmer-Magnus and DeChurch, 2009).

The second dimension of voice is its content. Voice about improvements or existing failures in the change process has been associated with positive organisational outcomes, such as team learning, improved work processes, innovation and crisis prevention (Edmondson, 1999; Schwartz and Wald, 2003). To include the expression of both constructive suggestions and concerns relating to changes (proposed or enacted), some researchers have distinguished between promotive (to improve existing work practices and procedures - Van Dyne and LePine, 1998) and prohibitive (expressions of individuals' dissent and concern about existing or impending practices - Rusbult et al., 1988) aspects of voice, with less attention paid to the latter. Voice, indeed, can be critical and signal an actor's disengagement with an organisation and its practices. The effects of both types of voice contents may not necessarily lead to improvements or positive outcomes for the organisation. In accounting, voice processes have been investigated mostly in relation to budgeting. Participative budgeting research has assumed a subordinate can influence their budget target and provide input to the process (Otley et al., 1994). Byrne and Damon (2008), analysing multiple time periods, found that, generally, subordinates who are given a voice in the budgeting process, but for whom suggestions contained in the voicing are not reflected in final budget allocations, perform better going forward if they receive an explanation of such a decision.

Of course, the categories proposed to identify the direction (vertical versus horizontal) and content (promotive versus prohibitive) of voice represent the extremes of a spectrum along which different behaviours and combinations can intertwine. The classifications proposed in this paper are only a simplification of reality and aim to be a first step to reconcile and investigate the two dimensions together. These categories are not exhaustive and more studies are needed in this respect. In simplifying such reality, this paper argues that actors' accounts expressed through potentially different voice processes can, however, capture crucial aspects of information transmission between the organisational members involved in, and affected by, change (Lines, 2005). Any type of change, indeed, entails a dialogue between participating actors, bringing together arguments from differing views, and individuals with different goals and backgrounds (Chattopadhyaty et al., 1999). Such dialogues and accounts, however, can be given regardless of the actual level of participation in reaching a certain decision. The construction of individual legitimation or delegitimation around a change (where change may be seen as either justifiable or unjustifiable) is also reflected in the use of semantics and structures expressing positive or negative connotations. Actors can contribute to the process of change not only by expressly voicing their concerns in the ways here reviewed, but also through the implicit legitimation or delegitimation of the change itself, which eventually is likely to affect the way changes are implemented and embed. While these aspects pertain to the level of talk and decision making (Brunsson, 1989a, 1989b), it is important to stress that the final results of a process of change will strongly mirror the actual actions, and not only the talk, that were taken subsequently or as a result of a decision ${ }^{\text {iv }}$.

\subsection{Legitimation and Delegitimation of Change}

A preliminary condition for the implementation of change is that it has to be considered 'legitimate' within the very context in which it is to be applied, with delegitimation more likely to hamper any change process. In order to explain why the introduction of a new practice succeeds or fails in a certain institutional field, it is essential to understand how actors legitimate (justify) or delegitimate (criticise) the change and the arguments they mobilise for it. In the field research reported in this paper, six specific legitimation (or delegitimation) strategies are used to analyse the captured data (see Table 1).

\section{Table 1 here}


Specific context conditions define the ideas considered 'sensible', the constructions of reality that are seen as 'realistic', and the claims are held as 'legitimate' within a certain policy (Koopmans and Statham, 1999). In legitimating or delegitimating change, the exercise of voice and the related language can play an important role for change diffusion and implementation, as well as its abandonment and failure (Strang and Meyer, 1994; Green, 2004). The rhetorical arguments and strategies set in place during a process of change can strengthen or weaken the adoption of new practices and the way actors validate the change itself (Hirsch, 1986; Green, 2004). However, how rhetoric and language shape the introduction and reproduction of change within organisations and at an individual level has been little investigated in the past and, especially, how legitimation (or delegitimation) strategies are used to achieve change is still unclear (Vaara et al., 2006; Green et al., 2008).

Studies focusing on accounting change and (de)legitimation have only seldom investigated the way changes are framed (Andon and Free, 2012; Hyndman and Liguori, 2017), more often limiting the analysis to accounting narratives and documents (Aerts, 2001 and 2005; Clatworthy and Jones, 2003). In the public sector, change has been most often viewed as triggered by external institutional pressures, where legitimation comes as a consequence of isomorphic behaviours (Ezzamel et al., 2007; Jones and Mellett, 2007). Looking at the UK, Hyndman and Liguori (2017) argued that changes introduced to enhance 'rational' decision making are often perceived more in terms of being pushed by authority. However, for radical change to embed, they argued that it is necessary for change to be supported by the actors' use of rationalisation strategies and arguments, rather than being seen as predominantly driven by authorisation-based pressures.

According to Green and Li (2011) and Vaara et al. (2006), new techniques and ideas can be put forth or resisted relying on one or more among five discursive strategies: authorisation, rationalisation, normalisation, moralisation or narrativisation. Authorisation refers to (de)legitimation through authority of tradition, custom, law and persons upon whom institutional authority of some kind has been bestowed. Rationalisation is related to (de)legitimation by institutionalised social action and knowledge that society has constructed, giving the proposed change(s) cognitive validity. Such a strategy mainly focuses on the benefits and costs, purposes or outcomes that a certain course of action can bring. Normalisation (de)legitimates by exemplarity that can involve 'retrospective' (similar cases, events or practices in the past) or 'prospective' (new cases, events or practices to be expected) references, which make the case at hand something more or less 'normal'. Moralisation refers to (de)legitimation by reference to specific value systems. Finally, narrativisation is about (de)legitimation and sense giving conveyed through narratives; telling a story can provide evidence of acceptable or resisted behaviour, or preferred or unwanted behaviour. Green and Li (2011) also identify a route of legitimation and delegitimation via pathos, i.e. by appealing to emotions, which does not necessarily coincide with the above strategies (making a total of six strategies mobilised in this paper - as per Table 1). Each strategy can be used either to legitimate and support change, or delegitimate and resist it. The variation in the acceptance of a particular change depends upon deployment of specific arguments in a particular situation. Legitimation and delegitimation strategies are not always intentional or conscious (Green, 2004), but they always play a role in creating organisational conditions that can help to restore or justify social status quos, or can even destroy them. In order to undermine or stop change, different actors can use antagonistic strategies, criticising the validity or ridiculing the source of information (Lefsrud and Meyer, 2012).

\section{METHODS}

This paper explores possible patterns and relationships between organisational voice processes (as recalled by the interviewees with respect to themselves and others, at the time changes were announced, discussed and implemented), and individual legitimation strategies subsequently employed by the actors (the interviewees) to understand and legitimate (or delegitimate) these 
changes. The paper is based on the comparative case studies (Patton, 2002; Yin, 2014) of the Westminster central government and the Scottish devolved administration. The choice of such cases aimed at facilitating the study and understanding of different possible targets and channels of voice processes. Indeed, in the cases under analysis, both vertical and horizontal voice can be potentially expected to play an important role during change, where the former, in particular, can be directed to departments and individuals both within and outside each of the organisations studied in this paper. International comparisons of the public-sector managerial reforms that took place from the 1990s onwards have also indicated that these have been implemented at a quicker pace and more enthusiastically in the UK, compared to other countries (Pollitt and Bouckaert, 2011). Such reforms deeply involved the implementation of, so called, 'modern' accounting systems (Hyndman and Lapsley, 2016) and also brought about a process of decentralisation and devolution of government, which has fostered the increased independence of 'devolved administrations'. The UK, and especially the comparison of the cases of Westminster central government and the devolved administration of Scotland, as an example of a high-intensity adopter of new managerial ideas and tools, provides an interesting context to investigate how similar accounting changes can be implemented and legitimated differently at different organisational and jurisdictional levels.

Exploring (de)legitimation strategies and voice processes required asking organisational actors about their experiences and perceptions. This involved conducting semi-structured interviews to reconstruct the understanding of the key actors as to the main accounting changes affecting their departments over the previous three decades. While the interviewees were prompted when a specific area of change (see Figure 1) had not been discussed, they were left free to indicate what the main changes were as perceived by them, and many important aspects of such changes emerged during the interviews themselves, as the participants made sense of them. Questions were asked about the most relevant accounting changes and their sources, what was said (by whom and to whom) when the changes were announced, discussed and implemented, and the interviewees' reactions and views of such changes.

Thirty-four interviews were conducted with senior managers in 2014-15 (18 in Westminster and 16 in Scotland), who were responsible for both policy and accounting issues. Besides the two finance departments (Her Majesty's Treasury - HMT - in Westminster, and Scottish Finance - SF - in Scotland), line operational departments (identified as WD and SD for Westminster and Scotland respectively) were also considered. The interviews in operational departments were carried out with key actors in the areas of rural development and higher education ${ }^{\mathrm{v}}$. While the finance departments had the task of translating the political ideas into technical requirements and pushing the accounting changes down into the rest of the organisation, the operationally-focused departments had to translate the changes into their everyday activities.

Steps were taken in selecting interviewees to ensure that they had either 'lived-through' and/or had good knowledge of the accounting changes that had occurred and which were the focus of the study. This was achieved by engaging with senior staff (and academic contacts) to steer the researchers regarding interview targets in the two jurisdictions and, in some cases, interviewing staff who were previously employed, but had subsequently retired. The overall average tenure in the public sector of the interviewees was over 17 years, 15 years for Westminster and 20 years for Scotland (see Table 2, which shows such tenure, together with: the number and percentage of interviewees who were professionally-qualified accountants, and similar information relating to whether they had precious private-sector experience). In Westminster, the slightly lower tenure in the public sector and the higher mobility of civil servants (together with the greater tendency of movement from private to public sector) may have influenced some of the interviewees' replies. However, overall, the interviewees had a high degree of continuity of service and were considered as possessing the ability to reflect on the changes that were the object of the study. Many of these changes occurred during the tenure of the key actors interviewed. In addition, from the interviews, it was clear that the history of most of the other changes, which may have predated their 
appointment, were well known (and often discussed in the work setting). ${ }^{\mathrm{vi}}$ Interviewees were therefore aware of the pre- and post-change positions. Moreover, given that the interviews focused on ex-post legitimation and voice processes, it was considered that the interviewees had the ability to provide informed views/perceptions.

\section{Table 2 here}

The interviewees are noted in any quotations included in the paper by the designations: HMT (HMT1 to HMT4), SF (SF1 to SF8), and WD1 to WD14 and SD1 to SD8 for the operational departments' interviewees in Westminster and Scotland respectively. The interviewees were identified through snowball sampling (Patton, 2002). Each interview lasted for about one hour and was recorded and transcribed in full for coding. The coding scheme, based on previous literature and theoretical coding (Patton, 2002), was applied to each of the interviews independently by the researchers, with all cases of disagreement being reviewed and resolved as a team (coding and analysis supported by the software ATLAS.ti 6).

Following the categories proposed in the literature review, during the analysis, the voicing process was reconstructed from the interviewees' responses on the basis of examples and references made to the channels they and their colleagues used to express their opinion (i.e. the direction of voice) and to the type of opinion that was expressed (i.e. the content of voice). Different processes were identified and classified through the accounts given in relation to how change happened and how the organisation reacted/voiced views relating to the proposals and any concerns/criticisms. The direction of the voice process was identified as either ${ }^{\text {vii }}$ : (i) horizontal, across co-workers/peers in the same department (e.g., peers in HMT or SD) or across different departments at the same level (e.g., other line departments); (ii) vertical, towards a hierarchically senior department, which, in this study, is identified as an operational department towards HMT (for operational departments in Westminster - WD) or SF (for operational departments in Scotland - SD); (iii) vertical within a department (towards a superior); or (iv) vertical towards individuals, organisations or units outside the specific organisation (e.g., a Scottish department towards HMT). Supportive opinions and ideas expressed through different channels were coded as promotive voice, while dissent and concerns (criticisms) were classified as prohibitive voice. It should be noted that the perceptions about the voice processes were collected and aggregated for each possible area of change (financial accounting, budgeting or performance management) in relation to the two case studies (Westminster and Scotland).

As far as the legitimation and delegitimation strategies are concerned, these were elicited from the interviewees' responses so as to identify the way they themselves thought about the changes and how they individually made sense of them subsequently (regardless of their recollections of the voice processes followed when the changes were initially announced, discussed and implemented). An argument was coded when a legitimation strategy was used with regard to one of the possible areas of change or relating to the reforms as a whole. Six legitimation/delegitimation strategies were operationalised: authorisation, rationalisation, normalisation, moralisation, narrativisation and pathos. Following Hyndman and Liguori (2017), legitimation strategies were coded as ' 1 ', whereas delegitimation strategies were coded as ' 2 '. The analysis distinguishes between the Westminster and the Scottish governments/cases, presented by jurisdiction and by organisational level. While it is important to recognise that the results originate from qualitative analysis and coding, and as a consequence any frequencies and numbers are indicative and have to be interpreted with care, following previous studies, the paper presents: the absolute counts and relative prevalence of each legitimation strategy (Table 3), and strategies by area of change (Tables 4 and 5). The number of occurrences for each strategy was computed so that a repetition of the same argument within the same answer was only counted once. It should be noted that a number of strategies could co-exist in the same argument. 


\section{DEVOLUTION WITHIN THE UK: THE SCOTTISH ARRANGEMENT}

Traditionally, government within the UK has been founded on concepts such as a unitary state and the supremacy of a parliament at Westminster. Up until the late 1990s the UK operated as a very centralised state, with substantial powers exercised by the Westminster parliament in London. Latterly, these ideas have been challenged by the process of devolution, with, during the 1980s and 1990s, a significant increase in support for greater devolution in Northern Ireland, Scotland and Wales. In Scotland, the idea of an elected parliament emerged, and when a referendum on devolution was called in 1997, Scotland voted in favour with $74.3 \%$ of those voting being supportive.

Subsequent to the vote for devolution, the Scotland Act 1998 introduced the Scottish parliament, which started its first legislative period in July 1999. In the area of accounting, a Consultative Steering Group and a Financial Issues Advisory Group (FIAG) ${ }^{\text {viii }}$ developed proposals for the practical operations of the new institution. The Scottish parliament has full legislative competence (that is to say it holds primary legislative powers) across a wide range of domestic policy areas.

\subsection{Change in the UK and Scotland}

Over a period spanning approximately three decades, accounting systems in all parts of UK central government changed considerably. Initially, UK central government featured: cash budgeting with strict annuality requirements, cash accounting and limited performance measurement and performance management. Since then, and on a UK-wide basis, it has progressively moved significantly along a continuum of modernisation with, subsequent to devolution in Scotland, particularly Scottish 'nuances' (largely relating to budgeting and performance management) on this path being developed (see Figure 1 for UK-wide changes and specifically Scottish features of these). ${ }^{\mathrm{ix}}$

The earliest significant changes were seen with respect to performance management (see Figure 1). The Financial Management Initiative (FMI) called for managers at all levels in central government to have (HM Government 1982, pp. 5) 'a clear view of their objectives, and means to assess, and wherever possible measure, outputs or performance in relation to those objectives'. This high-minded aspiration was a leitmotif in a range of later initiatives aimed at smaller, performance-focused public-service units. This heralded an extensive programme, referred to as the Next Steps Initiative, aimed at delivering better quality central government services for the benefit of taxpayers, customers and staff. Performance management and reporting were also integral parts of the development of Resource Accounting and Budgeting (RAB) changes in the mid-1990s and came again to the fore in the introduction of Public Service Agreements (PSAs) and Service Delivery Agreements (SDAs) in 1998 (with these being subsequently superseded by a greater emphasis on individual department planning and a requirement for more intensified output and impact targets in 2004 and 2010 respectively, Figure 1).

Since 1980 financial accounting has moved from its traditional cash base to a more commercial accrual base (Figure 1). A move from the cash basis was agreed for central government in the 1990s (a Green Paper, HM Treasury, 1994; being followed by a White Paper, HM Treasury, 1995). This change was implemented in full by 2001 under the title of Resource Accounting and Budgeting (RAB), with resource accounting, which extended financial accounting beyond the cashbased system used previously by applying accrual principles (and also integrating objectives and targets into the accounting system). The position of accrual accounting was further embedded by the decision in 1998 to produce Whole of Government Accounts (WGA) (a consolidated set of accrual financial statements for the UK public sector), although the first set of WGA was only produced in 2011 (see Heald and Georgiou (2009) for a discussion of the reasons for the delay). In addition, in 2007, it was announced that the financial statements of public-sector organisations 
would be prepared using International Financial Reporting Standards (IFRS); this was implemented by 2009 .

In the realm of budgeting, major changes also occurred (Figure 1). The move from cash budgeting to resource (accrual) budgeting was announced in the mid-1990s and was 'live' by 2003 . In addition, annuality (the requirement for budget allocations to be spent by the financial year-end or be surrendered to the centre) was abolished in 1997 at central government departmental level with end-year flexibility (EYF) being permitted (allowing the carry forward of unspent resources from one year to the next). However, as a consequence of financial pressures, this flexibility was removed in 2011. To provide greater long-term focus, in 1998, Treasury-led Spending Reviews were initiated to set firm and fixed spending budgets over several years for each government department rather than rely on single-period budgeting. In 2007, a Clear Line of Sight (CLOS) project was initiated to provide better alignment of accounting and budgeting boundaries (and an expansion of the departmental boundary).

From the 1980s until devolution in 1999, Scottish affairs were controlled directly by the Westminster parliament. Subsequent to devolution, the majority of UK financial accounting rules and changes continued to apply to Scotland. However, at this time, and with respect to budgeting and performance management in particular, modifications to systems and processes were made (Figure 1). In preparing for devolution, it was decided that it would not be appropriate for the Scottish parliament to merely adopt the existing practices of budgetary scrutiny of the UK parliament at Westminster for a range of reasons, including the need to ensure greater transparency (Scottish Office, 1998). As a consequence, the system of budget development and scrutiny adopted by the Scottish parliament became a three stage process (Ezzamel et al., 2014). In terms of performance management, Scotland experienced similar influences as the rest of the UK prior to devolution. Subsequently, while the focus on such was at least as intense as in the rest of the UK, the manner in which it was applied has been different. Perhaps the most notable outworking of this was seen in the Scottish Spending Review of 2007 which introduced a National Performance Framework (NPF). Based on an outcomes-based model developed for use in the state of Virginia in the USA, the NPF is an integrated, long-term framework that focuses on outcomes, rather than inputs and outputs (The Scottish Government, 2011). Overall, there has been a large degree of convergence on the main financial accounting and budgeting processes used by both the Westminster and Scottish parliaments, and when divergences have occurred, these have largely related to the more fine-grained application of devolved responsibilities, rather than the main tools of planning and control, and their related accounting instruments.

\section{Figure 1 here}

\section{THE CASE OF WESTMINSTER}

One of the main sources of accounting change in Westminster was HMT, one of 24 ministerial departments within the UK central government. HMT had overall responsibility for developing and executing the UK government's public finance and economic policy. A range of accounting changes were introduced under the auspices of HMT, purportedly in order to facilitate modern, effective management in the more-operationally-focused departments. On the side of the receivers of change analysed in the study, rural development activities fell within the competencies of the Department for Environment Food and Rural Affairs in the UK central government; higher education was the responsibility of the Department for Business Innovation and Skills.

\subsection{Voicing Processes in Westminster}


The Westminster interviewees, at all levels, were generally positive about the accounting changes and ideas promoted over the past decades. In both HMT and the line departments (WD), they underlined how accounting changes had been accompanied by a voicing process within Westminster that was mainly vertical (towards and from HMT) and overwhelmingly promotive (through committees, workshops and roundtables, where the general perception was that departments and individuals were brought together to cooperate in a constructive way):

'I remember who was actually standing up at the time and stating this is a good idea and we should do this - I cannot recall anyone [speaking against it] or any significant organised resistance to it.' HMT4 (referring to the voice process accompanying accounting reforms overall)

For a number of changes, the vertical aspect of voicing was perceived as directed both ways, to and from HMT, for instance, in relation to CLOS and RAB:

"When the Clear Line of Sight budgetary changes came through, I spotted an error and so I said "I don't think you want to do this, if you do this, you get an error." I did spot an error in the way they were approaching departments, so that got updated.' WD11 (referring to a financial accounting and budgeting change - CLOS - and the channels available to voice people's concerns)

Initially, departments weren't all together... There was scepticism about the way it was actually happening; a bit of scepticism in parliament which would say "No, we don't want to change the system". And people took quite a lot of persuading. There were emails going round, discussions in sessions, contentious issues bighlighted in reports, lots of ideas aired.' HMT1 (referring to the way in which RAB was developed)

This pattern was similar for each of the three areas of accounting change and also when the interviewees talked about the reform as a whole. The few times it was recalled, prohibitive voice was mostly recognised in a horizontal direction, although perceptions of its employment were limited. Very occasionally, interviewees recalled difficulty in expressing voice or recalled the use of prohibitive voicing from the line departments towards HMT (the designers of change):

We have a lot of input from Treasury. We don't do anything without Treasury's say [...] You bave to debate with Treasury, because you put in your bid by specific areas of spend [...] Then you are in debates with Treasury about how you are going... with student loans. You know that was a huge issue about how student loans should be formulated... So we don't do anything really without Treasury!' WD8 (referring to CLOS)

\subsection{Legitimation and Delegitimation of Change in the Westminster Finance Department}

As previous literature has suggested (Connolly and Hyndman, 2006), given that most Westminster finance department interviewees were professionally qualified accountants (many also having some private-sector experience), HMT interviewees predominantly referred to financial accounting changes (such as the introduction of resource/accrual accounting or WGA) during the interviews. When discussing the different areas of change, they concentrated strongly on legitimation strategies rather than delegitimation ones. As can be seen in Table 3 (which shows numbers and percentages of legitimation strategies and total delegitimation strategies by organisational level and government - Westminster and Scotland shown separately), delegitimation strategies (AUT2, MOR2, NAR2, NOR2, PAT2 and RAT2 combined) were only mentioned in 47 cases out of 315 counts $(15 \%)$ of all the HMT cases. In other words, consistent with the organisational voice process highlighted above, changes were largely interpreted by individuals through positive statements and with limited questioning in HMT. In terms of legitimation strategies, the most frequently employed concerned rationalisation (RAT1 24.4\%, Table 3), followed by authorisation 
(AUT1 22.2\%). While such percentages themselves may only be indicative, this order (RAT followed by AUT) was the same for each of the three areas of accounting change (see Table 4, which shows numbers and percentages of legitimation strategies and the total delegitimation strategies by area of accounting change in Westminster), but was reversed when the reform process as a whole was discussed (RAT1 21\% versus AUT1 22.6\%).

With respect to rationalisation, the interviewees reflected on the need for the new forms of account to support upward communication (to politicians) and within-department communication (to managers) as a basis for discussion and better decisions. This was particularly the case when talking about RAB. In HMT, rationalisation (RAT1) and narrativisation (NAR1) were often used together. Rational arguments were also frequently combined with the recognition of some sort of authority (mainly government and parliament), or with normalisation arguments. Interestingly, delegitimating strategies linked to rationality (RAT2) accounted for only about $5.7 \%$ of the cases in HMT (detail not shown in the tables). When used, this was not particularly with respect to the unsuitability of specific individual tools, but largely in relation to implementation problems connected to the initial misalignment between accounting and budgeting systems.

In the case of authorisation, the main sources of authority referred to were political or government, often mirroring a perceived top-down approach to change. Authority was seen to be pushing or supporting the changes, and, in most cases, this seemed to be appreciated (perhaps viewed as providing welcomed back-up to accounting changes that were considered 'rational' and 'normal' by the HMT interviewees). For instance, when looking back at the whole experience of managerial reforms:

'That's what started it off. They all started with political experience. Government departments started playing games. Mechanisms were then put in place to stop them from playing games.' HMT2

Normalisation arguments were also presented relatively frequently within HMT (NOR1 11.1\%, Table 3), often related to the role professionals played because of their specialised training and active involvement in networks. In this case, many of the accounting changes that had been introduced were viewed as positive because they related to 'what was professional' or what 'was done in the private sector'. For example, referring to the whole reform:

There is more of it [change] going on in some places than others, but unfortunately in some corners there's not much of it happening at all and again; it's why industry is so much better at it.' HMT1

HMT, like Westminster interviewees in general, made extensive use of narratives and stories to describe and assess the changes (Table 3). This evidence may have been strengthened by their long-term experience in the three areas of accounting change, where the first experimentations were already in place by the 1980s. Finally, it is worth noting that the HMT interviewees seemed relatively emotionally connected to the changes, with positive pathos strategies (PAT1) utilised in about $7.3 \%$ of cases (Table 3), a strategy especially used when referring to budgeting (Table 4). These numbers are much higher than in WD, where pathos was rarely found. The difference between the central finance function and the other departments regarding pathos may reflect the fact that HMT was, to an extent, the persuader and implementer of the accounting changes, whereas the other departments merely had the changes 'imposed' upon them.

Tables 3 and 4 here

\subsection{Legitimation and Delegitimation of Change by the Operationally-focussed Westminster Departments}


At the operational level, the interviewees referenced financial accounting and budgeting changes almost equally. This may be explained by the fact that, although the majority of the Westminster interviewees were accountants, relatively more of those working in WD were public-sector trained. These were, therefore, more likely, when thinking of accounting issues, to have greater awareness of aspects traditionally related to the public sector that were beyond a business-like financial accounting focus. This may explain the greater emphasis placed on budgeting in WD (budgeting being the traditional tool used in the public sector to steer and monitor policies). When looking at the legitimation strategies, the main strategy used overall and per area of change was rationalisation (RAT, Tables 3 and 4), and ideas relating to economic logic, control over resources, effective planning and optimal choice were often at the core of the responses:

'... the departments have to do a business plan, which was quite amusing, but part of the business plan was to identify the ministerial priorities, which makes sense.'WD1

and

'I think it $[\mathrm{RAB}]$ was to demonstrate costs in and around each department because before that we weren't; we were only thinking about the cash costs. You weren't ever thinking about any non-cash elements.' WD8

Interestingly, in WD, the few times that delegitimation was used, it was often related to rationalisation (RAT2, about $7.5 \%$ of all strategies used - detail not shown in the tables) and occurred much more frequently than in HMT. This was often used with reference to the reform as a whole and to financial accounting, rather than budgeting and performance management. Staff in the operational departments had more doubts about the meaning of what they were doing and the changes they were implementing. As a consequence, these were also more often perceived as authority-based and imposed.

The second most used strategy was authorisation (AUT, Table 3), where about $26.6 \%$ of the arguments were legitimated using AUT1 (often by reference to the role played by HMT and government, much less so to the EU), a higher level than in HMT. For instance, when referring to CLOS, and on being asked about who was promoting the change:

'Change comes pretty much from the centre, which is either Treasury or the Cabinet Office. Parliament also I think. Parliament pushed CLOS through. They were fed up with getting three different reports... and every one of those is correct; and parliament, I think, just got fed up with all the smoke and mirrors and the constant trying to reconcile between the three to get facts.' WD2

Similar to HMT, in order to legitimate the changes, authorisation was often presented together with rationalisation arguments. Narrativisation to legitimate change was also widely used in WD, being the third most frequent strategy (Table 3). This was often utilised in combination ${ }^{\mathrm{x}}$ with rational arguments as a means of justifying and strengthening the actors' perspective (recollection of events and stories helped answer the question 'why are we doing this?') and was particularly visible when the interviewees were making reference to performance-management changes (Table 4). Possibly reflecting the interviewees' background (more public-sector oriented), the use of normalisation strategies in WD was much lower than in HMT (Table 3), but, as in HMT, largely used in relation to financial accounting (Table 4). It is also interesting to note that NOR1 and RAT2 arguments were often used together (data not shown in tables), suggesting that even professionally-based and allegedly appropriate changes can be seen as irrational and criticised when their implementation appears imposed, unstructured and problematic. Differently from what was seen in HMT, finally, pathos arguments were almost totally absent in WD. This suggests that the further the actors implementing the changes were from the centre (where changes had been decided), the less committed and personally involved they appeared to be. 


\section{THE CASE OF SCOTLAND}

At the time of the interviews, the finance functions of the Scottish government (in this analysis referred to as SF) fell under the auspices of the Cabinet Secretary for Finance, Employment and Sustainable Growth and the Scottish Government Finance Directorate. Rural development activities were the responsibility of the Agriculture, Food and Rural Communities Directorate; with higher education being dealt with by the Employability, Skills and Lifelong Learning Directorate.

\subsection{Voicing Processes in Scotland}

Perhaps unsurprisingly, given their perceived greater distance from the centre of decision making with respect to accounting changes, the Scottish interviewees perceived the process of change in Scotland was less shared and agreed upon when compared to the views from Westminster. Consistently, the overall voicing process was perceived as more broken and less positive, with more examples of horizontal and prohibitive voice. Possibly because of their devolved and satellite position, people tended to channel or express dissent and complain about changes, especially with respect to financial accounting and budgeting. This was particularly the case with other colleagues and across directorates, but less so with vertical voicing directed towards SF or Westminster (where most of the changes originated):

'We met a bit of resistance within our own finance directorate. We had this heart of finance, a fairly small team driving the change in terms of resource accounting and accruals, and then we had finance teams that were interacting with directorates who weren't, at that time, led by professional staff. They were actually quite resistant.' SF2 (referring to financial accounting and evidence of prohibitive voice channelled among colleagues)

'They weren't able to communicate the messages; the other people just didn't speak to them [SF and Scottish Government]. They just didn't... It's like people did completely separate jobs, it wasn't part of the same thing.' SD8 (about the whole reform process and the difficulties in communicating with hierarchically higher levels)

The Scottish interviewees, however, felt particular ownership of the NPF as an organisational tool This appeared to be embraced, and used, in a few cases with respect to horizontal and promotive voicing; however, it was mainly utilised with prohibitive vertical voicing, as 'ammunition' to debate with Westminster (HMT):

'A lot said "Well, why are we reporting to Treasury?" But we get the funding; our funding all comes from Westminster. So regardless of whether you like it or not, we need to be able to report back on what we spent it on. So a lot of people thought "Oh right. It [the NPF] now gives me a stick to beat them with." SF4

While the process of change in budgeting was perceived as displaying similar voice processes and characteristics as performance management, in Scotland changes in financial accounting were either voiced in prohibitive terms through horizontal channels, or through vertical channels and promotive voice. For instance:

'A lot of people have never seen the point of this... Some of the old guys still find it very, very difficult, and I hear all the time - "Oh, why are we doing that?" SD8 (horizontal voicing referring to RAB)

and 
'I've put in my own concepts because I couldn't accept the process that the Scottish government uses, and it goes out to all sorts of people who don't understand what they're doing. As a result, we send information to Treasury about the drawdowns that are required here for cash ... So I use my own process to inform them of our cash needs: a proactive reporting of cash needs, not the centre sending something to us.' SD8 (vertical voicing referring to financial accounting)

\subsection{Legitimation and Delegitimation of Change in the Scottish Finance Department}

Unlike HMT, references to financial accounting, budgeting and performance-management changes in SF were of a fairly similar frequency. The perceived relevance of budgeting tools and systems may be explained by the emphasis placed by the interviewees on the differences between the 'Westminster model' and the Scottish budgeting cycle. Also performance management (often with reference to the NPF) was alluded to as a distinctive Scottish approach, where the interviewees could exercise autonomy in their policy planning and control:

The whole emphasis was a change to outcomes and, you know how short term governments can be. This [the $\mathrm{NPF}]$ was actually saying we should be working to outcomes for Scotland, but they'll not necessarily be able to be tested or demonstrated in the very short, monthly, quarterly cycles. This is the sort of strategic objectives... So this is completely different to PSAs and their outcomes; and all of our public sector is actually linked to outcome agreements, including local governments.' SF1

In terms of legitimation strategies, SF, perhaps not surprisingly, differed from their Westminster counterparts: here the interviewees made greater use of authorisation strategies (AUT1 representing about $25.3 \%$ of all the strategies used, Table 3 ). While the main authority mentioned by SF interviewees was usually the Scottish government, they also often combined this with reference to the role played by HMT in determining their overall resources and financial accounting policies (such as in the case of RAB and WGA). For instance:

'The policy is devolved so ministers can set their own statutes, their own outcomes, and these sorts of things. We just have to make sure we don't overspend and we send regular information to Treasury. We've built up a level of credibility with Treasury that what we say, we do. Our forecasts are pretty close to where we come out.'SF1

This is consistent with the picture given in Table 5 (showing numbers and percentages of legitimation strategies and total delegitimation strategies by area of accounting change in Scotland), where, with the exception of budgeting, all areas of accounting change were legitimated by SF more with authorisation rather than rationalisation arguments (the reverse was the case in HMT).

In SF, rationalisation and narrativisation both represented approximately $22 \%$ of the strategies employed to talk of the changes (Table 5). In particular, stories were often used in combination with rational arguments, especially to stress the importance of effective planning and control. Interestingly, and again different from HMT, normative and pathos arguments were much less present in Scotland. This could be because: although most interviewees had private-sector experience, relatively fewer, when compared to Westminster, were qualified accountants (possibly impacting negatively on their perceptions of the importance of professional standards and rules see Table 2); and/or, with the exception of the NPF, they did not feel ownership of many of the perceived 'Westminster-driven' changes (e.g., RAB, EYF and WGA). As a consequence, lower levels of personal and organisational commitment (i.e. pathos) were present. Finally, it is worth noting that delegitimation strategies (AUT2, MOR2, NAR2, NOR2, PAT2 and RAT2 combined) emerged relatively more often here than in Westminster. Overall, these represented about $21 \%$ of the total strategies used in Scotland (with similar levels in SF and SD), compared to an overall 14\% in Westminster (Table 3). While these numbers derive from qualitative coding, they suggest that 
SF interviewees, like Scottish ones in general, were more critical of the accounting reforms put in place over the past thirty years.

\subsection{Legitimation and Delegitimation of Change by the Operationally-focussed Scottish Departments}

The relative mentions of the areas of accounting change emerging from the SD interviews were similar to those in SF. However, here performance management was more discussed than financial accounting, probably also as a result of the strong influence of the EU requirements and the performance measures demanded by the Common Agricultural Policy (which were much less emphasised in Westminster).

In SD the two most used strategies (both around 22\%, Table 3) were rationalisation (similar to SF, concerning improved decision making and planning) and authorisation (with particular reference to the role of Scottish and UK government policies, SF and the EU), followed by narrativisation. Positive rationalisation arguments, in particular, were often supported by positive stories and narrative exemplifications (RAT1 and NAR1 used together):

Because we work in a sort of demand-led scenario (we don't know exactly bow many students are going to come to us for support and we're always trying to figure out what the student population is going to be), it's not an exact science. It's the best that you can do with the information that you bave, and we're always trying to get to that exact point of knowing how many students we are going to support. What are they all going to need, or what are they going to be entitled to?'SD8

In $\mathrm{SD}$, the greatest use of delegitimation strategies was made in relation to rational arguments (RAT2, about $10 \%$ of all strategies used - detail not shown in the tables), mainly with respect to financial accounting and budgeting changes. For instance, when speaking about WGA:

I can't understand the aspiration in trying to get a cohesive look at the whole of the government picture. I don't think I've ever actually looked at the finished product and I don't know what anyone could realistically use the information for.'SD1

\section{Table 5 here}

\section{DISCUSSION AND COMPARISON OF THE CASES}

When comparing the two cases, both the Westminster and Scottish interviewees identified the existence of voice processes during the changes. The opportunity to 'voice' was seen by many in a positive light, while the absence of such was often indicated as a source of dissent and dissatisfaction (see, in particular, the Scottish case in relation to the lack of vertical voice). In Westminster (different from Scotland), the process of accounting change (in each area of change) was perceived as giving rise to vertical (towards HMT) voice, with responses back to the speaker (in WD) from HMT. Here, change appeared to be pushed from inside the organisation and was perceived to be voiced mostly in constructive/promotive, rather than prohibitive, terms. The changes were viewed as designed and shaped by HMT, and WD tended to see them as 'organisational changes', pushed by an internal authority (be it HMT or government).

Looking at how such changes were subsequently understood and talked about, both HMT and WD saw them as mainly rational, although also backed by authorisation (with references frequently made to government and HMT) and narrativisation strategies. The changes in financial accounting and budgeting particularly (often perceived as emanating from HMT) elicited, perhaps understandably, pathos-related strategies in HMT (something much less visible in Scotland, where 
most changes were seen as externally imposed). The evidence suggests that having the possibility of contributing to the change, as well as having voice as changes were developed and implemented, strengthened the whole legitimation process and resulted in change being perceived as both positive and rational.

In Scotland most of the changes were felt as imposed from either SF/government or Westminster (the only exception being the NPF). Here, the voice process was mainly perceived as horizontal and prohibitive. As changes (such as RAB and EYF) were seen largely viewed as adjustments that were enforced by Westminster and could not be halted or prevented in Scotland, the dialogue took place mainly among peers or similar departments, in a 'venting-like fashion'. Here, voice assumed negative, more-critical connotations with, compared to Westminster, the much greater development and emergence of delegitimation strategies (especially with respect to rationalisation - e.g., 'there is no benefit').

In Scotland, change was talked about and legitimated mainly through the use of authorisation strategies, and less so seen as rational (in Westminster, this order was reversed). Normalisation, often evidenced by references to professional or private-sector experiences, was also much less frequently alluded to in the Scottish interviews. As discussed above, this can be explained by the fact that in Scotland, when compared to Westminster, fewer interviewees were professionally qualified accountants. The most interesting issues, however, emerged with regard to performance management and the NPF. This tool, perhaps mirroring particular political stances, was often seen as an instrument to exercise autonomy as a devolved administration and bring about change. The interviewees showed ownership and knowledge of the technical characteristics and rationales behind the framework, as well as its origins (the 'Virginia example') and the mimetic pressures around it.

Interestingly, Scottish interviewees tended to refer to a wider range of sources of authority (including local, UK-based and supranational bodies). These multiple layers and levels of government continuously interacting (e.g, with SF having to operate within certain parameters, rules and systems established by WF) most likely influenced perceptions in terms of 'who is really pushing the change', and influenced the ready identification of authorisation strategies. The existence of multiple layers of authority (often viewed as far removed from the local situation) also had an effect on the perceptions of the process of change and tended to inhibit vertical voice, and encourage prohibitive, horizontal voice. Similarly, and consistent with a search for identity and greater local autonomy, in all Scottish departments a stronger role played by delegitimation strategies was evident.

With specific reference to the NPF (perhaps also seen as an ideological exception), the interviewees showed their engagement differently, through horizontal promotive voice, as they tried to spread a positive vision among colleagues. In contrast, the (Westminster-led) process of changes in financial accounting was mainly characterised by prohibitive horizontal voice, with promotive vertical voice only marginal. This may have to do with the perception that such changes were coming from 'above', and there was very little flexibility for Scotland to shape them. As a consequence, managers tended to complain to peers and colleagues, but work out pragmatic solutions and be constructive 'vertically' regarding any possible implementation problems (so as to 'minimise collateral damage'). Consistent with previous findings (Mesmer-Magnus and DeChurch, 2009), concerns and complaints were mainly expressed within departments. Overall, the findings in Scotland are in line with previous literature on budgeting (Otley et al., 1994) in suggesting that, in the presence of accounting change, the further away the locus of control and ownership of the changes, the weaker, and more negative, legitimation and voice become.

Finally, and different from what may have been expected from previous literature which suggests a clear link between content of organisational voice processes and individual reactions (Edmondson, 1999 and 2003), the results in both Westminster and Scotland highlight that, regardless of the content and direction of voice perceived at the organisational level, legitimation (versus delegitimation) strategies dominated when subsequently describing the accounting 
changes. While perceptions of the voice process during change appear connected to the type of strategy (rationalisation versus authorisation) used to legitimate it afterwards, this does not seem to affect strongly the way changes are criticised and, ultimately, delegitimated (delegitimation strategies being much less present). This may suggest that, for more technical areas and practices, such as accounting, the actual structure, content and shape of the proposed changes are more important to the organisational actors implementing them than the voice process through which they are first implemented. If such technical aspects are perceived as viable and reasonable, delegitimation of change is limited, regardless of the type of voice process followed. An explanation for this finding can also be found in the strong 'compliance' culture that characterises all groups of interviewees (and the UK as a country in general) (Hyndman et al., 2014).

This study explored possible relationships between organisational voice processes during change and legitimation strategies subsequently used by the actors involved. In both Westminster and Scotland, voice processes seemed to define the context within which change was both designed and implemented. The importance of voice was mentioned and recognised by interviewees at all levels and governments. Regardless of the content and direction of voice, however, change was subsequently mostly talked about and legitimated in positive terms. Concerns about 'unavoidable' changes, perceived as unlikely to be adjusted, were mainly voiced laterally towards colleagues, rather than 'bosses' or a more-central financial department, with overall delegitimation only marginal.

Previous literature has suggested that the actual implementation of new accounting tools is normally different from what was planned in official documents, these often containing overoptimistic claims and rather unclear expected costs and outcomes (Connolly and Hyndman, 2006). While this study was carried out after most of the changes had taken place (thus allowing the interviewees time to form their own opinion on such changes and their actual effects on their organisation), the optimistic claims through which most accounting systems (e.g., RAB) were initially introduced may have contributed to create an aura of 'social desirability' that people may be unwilling to break. In a post-NPM context, where it is generally accepted that government has to be efficient and run in a business-like fashion, it becomes increasingly difficult to disagree or delegitimate tools on which such ideas have been built. This 'social desirability' may have influenced some of the results as well.

The findings are also in line with previous studies that described the UK as generally characterised by a pervasive culture of compliance towards changes and reforms. Studies on the UK, including the Westminster and Scottish governments, and, more in general, countries of Anglo-Saxon tradition, have indicated that the likelihood of change being openly delegitimated or resisted is much lower in these countries, as opposed to, for instance, Continental European ones (Hammerschmid and Meyer, 2005; Hyndman et al., 2014). It is suggested that this is because of a general culture of acceptance, where dissent may be seen as a culturally-inappropriate reaction (Hyndman et al., 2014; Hyndman and Liguori, 2017). Some of these factors may also contribute to explain the findings of this research.

The study also indicates that a voicing process perceived as promotive, where a conversation exists among different organisational levels, is more likely associated with the presence of legitimation based on rationalisation arguments. Although beyond the scope of this paper, the interviewees in Westminster (and some in Scotland when talking about the NPF) intimated the presence of a loop that, activated by a department's voice, facilitated engagement from 'above' that had the potential to craft and fine-tune the changes. This often helped to strengthen the legitimation process, making it more positive and perceived as more rational. By contrast, the existence of multiple layers of authority, which was more pronounced in Scotland, may encourage legitimation of change based on authorisation and is likely to be associated with a more prohibitive voice process. Both the position (or locus) and the context of the organisational actors involved in the change, thus, seem to be relevant in influencing both perceptions of the voice process and subsequent legitimation strategies used. However, this does not appear to overly influence the 
emergence of delegitimation of change, which was less relevant regardless of the perceived voicing process.

\section{CONCLUSIONS}

The research and case studies comparison presented in this paper makes a threefold contribution. First, existing studies still struggle to explain organisations' heterogeneity and practice variation and, in many cases, accounting has been assumed to converge towards the adoption of common practices (Christensen and Lægreid, 2007). This study sheds more light on the individual processes of implementation and (de)legitimation that may lead to different organisational results. Second, while previous studies mainly focused on the content of voice (prohibitive versus promotive) or its direction (Liang et al., 2012), this paper has brought these two dimensions together in a more organic way, looking at change in a calculative practice (accounting), and proposing patterns and relationships associated with it. Finally, the study has linked voice processes during change and individual (de)legitimation, as part of broader organisational dynamics (Hyndman and Liguori, 2017). The paper suggests that promotive voice is more likely to be associated with rational legitimation of change, while prohibitive voice processes are more likely linked to the use of authorisation arguments to give sense to change. The paper argues that while the process of change may be led by either vertical or horizontal processes of voice (promotive or prohibitive), the way actors delegitimate and criticise/oppose change may not necessarily mirror the type of voice expressed. It is suggested that other personal and contextual factors may play a strong role in influencing actors' perceptions and behaviours.

From a managerial perspective, this research improves the current understanding of how accounting changes are implemented and legitimated at the individual level. The research suggests that the involvement of operationally-focussed managers in the development, as well as in the early-implementation process, of change will not only provide opportunities to affect change processes (possibly in a positive manner as more contextual variables relating to the change are considered), but also give managers more opportunities for voice and provide the potential for further legitimation (especially in terms of pathos, but also in terms of rationalisation) afterwards. The findings highlight that there is no right way to express one's voice, as both vertical and horizontal processes of voice, as well as promotive and prohibitive voice, can be interwoven with a number of different interpretations and perceptions of change. What should really be taken into consideration in order to predict possible reactions to a change is the organisational locus (where change is pushed from vs. where actors are located), the type of change and the context where it is being introduced.

The research presented in this paper is novel in terms of its investigation of accounting change, as it reflects an initial attempt to explore voice processes (i.e., their direction and content) and legitimation strategies used by actors involved in the change process. Yet, it has limitations (which the authors clearly recognise) and encouragement is provided to others to build on its foundation. First, the empirical study focused purely on the UK, an early and strong reform initiator. Other studies comparing different countries, with differing administrative cultures and traditions, would enrich the findings. Scotland, moreover, has only had a functioning devolved administration since 1999. While this was acknowledged in this research, actors' limited autonomy in relation to certain changes, and their ex-post rationalisation of changes that had taken place in the past (before 1999) may have influenced some of the results. Second, the voice process was explored only in terms of its content and direction, presenting this as dichotomous (vertical or horizontal, and promotive or prohibitive). These, however, represent extremes on a spectrum along which different combinations are possible. The classifications used in this analysis was a first step to consider these two dimensions of the voice process together. However, such categorisation is clearly not exhaustive and more nuanced studies might deepen understanding. For example, while these dimensions represent a simplification, voice may in reality be characterised also by other important 
aspects (such as tone and intensity). These would only be observable at the time the talk and discussion relating to particular changes take place, suggesting another limitation of this study. Further studies are also needed to explore such dynamics and address possible effects of voice frequency and strength on the final outcome of change. In particular, the paper has focused on vertical voicing towards a superior. Further research may investigate the loop that the reaction to such voicing may generate and the cycle of voicing between superiors and those below them (or the effect of horizontal voicing, and looped horizontal voice episodes, on the likelihood and manner of vertical voicing). The analysis of the actions and results that actually followed the talk and the decisions investigated was outside the scope of this paper. However, actions represent an essential part of any process of change. Additional studies are needed to compare and discuss how speech and actions interweave and affect each other, and how these may also lead to unwanted and negative consequences in the process of change. Finally, although we interviewed senior key actors (including some who had just retired at the time of the interviews) who had been directly involved in the process of change and had long tenure, the study does not include the views of those who, when faced with change, chose exit rather than voice. More research is needed to look at the frequency of such behaviours and their causes and effects. 


\section{REFERENCES}

Aerts, W. (2001). Inertia in the attributional content of annual accounting narratives. European Accounting Review, 10 (1), 3-32. https://doi.org/10.1080/09638180122562.

Aerts, W. (2005). Picking up the pieces: impression management in the retrospective attributional framing of accounting outcomes. Accounting, Organizations and Society, 30(6), 493-517. https://doi.org/10.1016/j.aos.2004.07.001.

Andon, P., \& Free C. (2012). Auditing and crisis management: The 2010 Melbourne Storm salary cap scandal. Accounting, Organizations and Society, 37(3), 131-154. https://doi.org/10.1016/j.aos.2012.01.004.

Brinsfield, C., Edwards M., \& Greenberg J. (2009). Voice and silence in organizations: Historical overview and current conceptualizations. In J. Greenberg, \& M. S. Edwards (Eds.), Employee Voice and Silence in Organizations (pp. 3-33). Bingley, UK: Emerald Group.

Brown, T.L. \& Potoski M. (2003). Transaction Costs and Institutional Explanations for Government Service Production Decisions. Journal of Public Administration Research and Theory, 13(4), 441-468. https://doi.org/10.1093/jopart/mug030.

Brunsson N. (1989). The organization of hypocrisy: Talk, decisions, and actions in organizations. New York: John Wiley \& Sons.

Brunsson, N. (1989). Reform as Routine. Scandinavian Journal of Management, 5 (3), 219-28. https://doi.org/10.1016/0956-5221(89)90028-6.

Brunsson N, \& Olsen JP. (1993). The reforming organization. London: Routledge.

Byrne, S., \& Damon F. (2008). To participate or not to participate? Voice and explanation effects on performance in a multi-period budget setting. The British Accounting Review, 40, 207-227. https://doi.org/10.1016/j.bar.2008.04.001.

Chattopadhyay, P., Glick, W.H., Miller, C.C., \& Huber, G.P. (1999). Determinants of executive beliefs: Comparing functional conditioning and social influence. Strategic Management Journal, 20, 763-789. https://doi.org/10.1002/(SICI)1097-0266(199908)20:8<763::AID-SMJ46>3.0.CO;2D.

Christensen, T., \& Lægreid, P. (2007). Transcending New Public Management. The transformation of public sector reforms. Aldershot: Ashgate.

Clatworthy, M., \& Jones, M.J. (2003). Financial reporting of good news and bad news: Evidence from accounting narratives. Accounting and Business Research, 33(3), 171-185. https://doi.org/https://doi.org/10.1080/00014788.2003.9729645.

Connolly, C, \& Hyndman, N. (2006). The actual implementation of accruals accounting: Caveats from a case within the UK public sector. Accounting, Auditing \& Accountability Journal, 19 (2), 272290. https://doi.org/10.1108/09513570610656123.

Contrafatto, M., \& Burns, J. (2013). Social and environmental accounting, organisational change and management accounting: A processual view. Management Accounting Research, 24, 349-365. https://doi.org/10.1016/j.mar.2013.10.004.

Detert, J.R., Burris, E.R., Harrison, D., \& Martin, S.R. (2013). Voice Flows to and around Leaders: Understanding When Units Are Helped or Hurt by Employee Voice. Administrative Science Quarterly, 58(4), 624-668. https://doi.org/10.1177/0001839213510151.

Edmondson, A.C. (1999). Psychological safety and learning behavior in work teams. Administrative Science Quarterly, 44, 350-383. https://doi.org/10.2307/2666999.

Edmondson, A.C. (2003). Speaking up in the operating room: How team leaders promote learning in interdisciplinary action teams. Journal of Management Studies, 40, 1419-1452. https://doi.org/10.1111/1467-6486.00386.

Ezzamel, M., Hyndman, N., Johnsen, A., \& Lapsley. I. (2014). Reforming central government: an evaluation of an accounting innovation. Critical Perspectives on Accounting, 25(4-5), 409-422. https://doi.org/10.1016/j.cpa.2013.05.006. 
Ezzamel, M., Robson, K., Stapleton, P., \& McLean, C. (2007). Discourse and institutional change: Giving accounts and accountability. Management Accounting Research, 18(2), 150-171. https://doi.org/10.1016/j.mar.2007.03.001.

Green, S.E. (2004). A rhetorical theory of diffusion. Academy of Management Review, 29(4), 653-669. https://doi.org/10.1177/014920630002600602.

Green, S.E., \& Li, Y. (2011). Rhetorical institutionalism: Language, agency, and structure in institutional theory since Alvesson 1993. Journal of Management Studies, 48(7), 1662-1697. https://doi.org/10.1111/j.1467-6486.2011.01022.x.

Green, S.E., Babb, M., \& Alpaslan, C.M. (2008). Institutional field dynamics and the competition between institutional logics. Management Communication Quarterly, 22(1), 40-73. https://doi.org/10.1177/0893318908318430.

Guthrie, J., Humphrey, C, Jones, L., \& Olson O. (2005). Debating public sector management and financial management reforms: an international study. Greenwich, CT: Information Age Publishers.

Hammerschmid G, \& Meyer R.E. (2005). New Public Management in Austria: Local variation on a global theme?. Public Administration, 83, 709-33. https://doi.org/10.1111/j.00333298.2005.00471.x

Heald, D., \& Georgiou, G. (2009). Whole of government accounts developments in the UK: Conceptual, technical and timetable issues. Public Money \& Management, 29(4), 219-27. https://doi.org/10.1080/09540960903034976.

Hirsch, P.M. (1986). From ambushes to golden parachutes: Corporate takeovers as an instance of cultural framing and institutional integration, American Journal Sociology, 91(4), 800-837. https://doi.org/10.1086/228351.

Hirschman, A. (1970). Exit, Voice, and Loyalty: Responses to Decline in Firms, Organizations, and States. Cambridge, MA: Harvard University Press.

HM Government (1982). Efficiency and effectiveness in the civil service (Cmnd. 8616). London: The Stationery Office.

HM Treasury (1994). Accounting for taxpayer's money: Resource accounting and budgeting in government, a consultation paper (Cmnd. 2626). London: The Stationery Office.

HM Treasury (1995). Better accounting for taxpayer's money (Cmnd. 2929). London: The Stationery Office.

Hyndman, N., \& Lapsley, I. (2016). New Public Management: The Story Continues. Financial Accountability \& Management, 32(4), 385-408. https://doi.org/10.1111/faam.12100.

Hyndman, N., \& Liguori, M. (2017). Achieving radical change: a comparative study of publicsector accounting in Westminster and Scotland. Accounting, Auditing \& Accountability Journal, 31(2), 428-455. https://doi.org/10.1108/AAAJ-04-2016-2527.

Hyndman, N., Liguori, M., Meyer, R. E., Polzer, T., Rota, S., \& Seiwald, J. (2014). The translation and sedimentation of accounting reforms. A comparison of the UK, Austrian and Italian experiences. Critical Perspective on Accounting, 25(4-5), 388-408. https://doi.org/10.1016/j.cpa.2013.05.008.

Jones, M., \& Mellett, H. (2007). Determinants of changes in accounting practices: Accounting and the UK Health Service. Critical Perspectives on Accounting, 18(1), 91-121. https://doi.org/10.1016/j.cpa.2005.05.003.

Keating, M. (2005). Policy Convergence and Divergence in Scotland under Devolution. Regional Studies, 39(4), 453-463. https:// doi.org/10.1080/00343400500128481.

Koopmans, R., \& Statham, P. (1999). Ethnic and Civic Conceptions of Nationhood and the Differential Success of the Extreme Right in Germany and Italy. How Social Movements Matter. Minneapolis: University of Minnesota Press.

Lefsrud, L.M., \& Meyer, R.E. (2012). Science or science fiction? Professionals' discursive construction of climate change. Organization Studies, 33(11), 1477-1506. https://doi.org/10.1177/0170840612463317. 
Liang, J., Farh, C., \& Farh, J.L. (2012). Psychological Antecedents of Promotive and Prohibitive Voice: A Two-Wave Examination. Academy of Management Journal, 55(1), 71-92. https://doi.org/10.5465/amj.2010.0176.

Lines, R. (2005). How social accounts and participation during change affect organizational $\begin{array}{llll}\text { learning. Journal of Workplace Learning, 17(3), } & \text { 157-177. }\end{array}$ https://doi.org/10.1108/13665620510588680.

Liu, W., Zhu, R., \& Yang, Y. (2010). I warn you because I like you: Voice behavior, employee identifications, and transformational leadership. Leadership Quarterly, 21, 189-202. https://doi.org/10.1016/j.leaqua.2009.10.014

Mesmer-Magnus, J.R., \& DeChurch, L.A. (2009). Information sharing and team performance: A meta-analysis. Journal of Applied Psychology, 94, 535-546. https://doi.org/10.1037/a0013773.

Midwinter, A. (2000). The Politics of Devolution Finance. In A. Wright (Ed.), Scotland: the Challenge of Devolution. Farnham: Ashgate Publishing.

Otley, D., Hannakis, L., \& Lindsay, R.M. (1994). Influence in budgeting, locus of control and organizational effectiveness: Cultural differences. Accounting and Business Review, 1(1), 29-42.

Patton, M.Q. (2002). Qualitative Research and Evaluation Methods. London: Sage Publications.

Pollitt, C., \& Bouckaert, G. (2011). Public sector reform. A comparative analysis: New public management, governance, and the neo-Weberian state (3rd ed.). Oxford: Oxford University Press.

Rusbult, C.E., Farrell, D., Rogers, G., \& Mainous, A.G. (1988). Impact of exchange variables on exit, voice, loyalty, and neglect: An integrative model of responses to declining job satisfaction. Academy of Management Journal, 31, 599-627. http://dx.doi.org/10.2307/256461

Schwartz, J., \& Wald, M.L. (2003). The Nation: NASA's curse? "Groupthink" is 30 years old, and still going strong. New York Times, March 9, 5.

Scottish Office (1998). Principles of the Scottish Parliament's Financial Procedures: Final Report by the Financial Issues Advisory Group. Edinburgh: Scottish Office.

Shapiro, D. (1993). Reconciling theoretical differences among procedural justice research by reevaluating what it means to have one's views 'considered.' Implications for third party managers. In R. Cropanzano (Ed.), Justice in the Workplace: Approaching Fairness in Human Resources Management (pp. 51-78). NJ: Erlbaum: Hillsdale.

Strang, D., \& Meyer, J.W. (1994). Institutional conditions for diffusion. In R.W. Scott, \& J.W. Meyer (Eds.), Institutional environments and organizations: Structural complexity and individualism (pp. 100111). Thousand Oaks, CA: Sage.

The Scottish Government (2011). An Introduction to Scotland's National Performance Framework, Scotland: APS Group Scotland. Accessed 30 ${ }^{\text {th }}$ May 2017 at: http://www.scotland.gov.uk/Resource/Doc/933/0124200.pdf

Vaara, E., Tienari, J., \& Laurila, J. (2006). Pulp and paper fiction: On the discursive legitimation of global industrial restructuring. Organization Studies, 27(6), 789-810. http://dx.doi.org/10.1177/0170840606061071.

Van Dyne, L., \& LePine, J. (1998). Helping and voice extra-role behaviors: Evidence of construct and predictive validity. Academy of Management Journal, 41, 108-119. http://dx.doi.org/10.2307/256902

Van Dyne, L., Cummings, L., \& McLean Parks, J. (1995). Extra-role behaviors: In pursuit of construct and definitional clarity. In B. M. Staw \& L. L. Cummings (Eds.), Research in organizational behaviour (pp. 215-285), 17. Greenwich, CT: JAI.

Yin, R. (2014) Case Study Research: design and methods. 5 ed. Thousand Oaks, CA: Sage. 


\section{Tables}

Table 1 - Legitimation (and delegitimation) Strategies Operationalised in the Field Research

\begin{tabular}{|c|c|}
\hline $\begin{array}{c}\text { LEGITIMATION } \\
\text { (OR } \\
\text { DELEGITIMATION) } \\
\text { STRATEGY }\end{array}$ & $\begin{array}{l}\text { DESCRIPTION OF THE STRATEGY IN ITS POSITIVE } \\
\text { (LEGITIMATION) FORM }\end{array}$ \\
\hline Authorisation & Legitimation through authority of tradition or law or position. \\
\hline Rationalisation & $\begin{array}{l}\text { Legitimation by considering the benefits, purposes or outcomes that a certain course } \\
\text { of action can bring. }\end{array}$ \\
\hline Normalisation & $\begin{array}{l}\text { Legitimation by seeing something as normal in terms of, for example, professional } \\
\text { standards or what is done elsewhere (possibly, in the business sector). }\end{array}$ \\
\hline Pathos & $\begin{array}{l}\text { Legitimation by appealing to emotions; something you are really committed to (for } \\
\text { whatever reason). }\end{array}$ \\
\hline Moralisation & $\begin{array}{l}\text { Legitimation by reference to specific value systems; it is right, for instance because it } \\
\text { supports transparency or accountability. }\end{array}$ \\
\hline Narrativisation & $\begin{array}{l}\text { Legitimation conveyed through narratives; telling a story can provide evidence of an } \\
\text { approach that is acceptable or appropriate. }\end{array}$ \\
\hline
\end{tabular}

Table 2 - Profile of Interviewees in Westminster and Scotland

\begin{tabular}{|c|c|c|}
\hline & WESTMINSTER & SCOTLAND \\
\hline $\begin{array}{c}\text { Number of interviewees } \\
\text { public sector (years) } \\
\text { puge length of service in the }\end{array}$ & 18 & 20 \\
\hline $\begin{array}{c}\text { Number (and \%) of professionally } \\
\text { qualified }\end{array}$ & 15 & $11(69 \%)$ \\
\hline $\begin{array}{c}\text { Number (and \%) with private- } \\
\text { sector experience }\end{array}$ & $7(39 \%)$ & $8(50 \%)$ \\
\hline
\end{tabular}


Table 3 - Legitimation (and delegitimation) Strategies in Westminster and Scotland

\begin{tabular}{|c|c|c|c|c|c|c|c|c|}
\hline \multicolumn{9}{|c|}{ WESTMINSTER } \\
\hline & AUT1 & MOR1 & NAR1 & NOR1 & PAT1 & RAT1 & $\begin{array}{c}\text { Total delegitimation } \\
\text { strategies }\end{array}$ & Total counts \\
\hline \multirow{2}{*}{ HMT } & $22.20 \%$ & $0.30 \%$ & $19.70 \%$ & $11.10 \%$ & $7.30 \%$ & $24.40 \%$ & $14.92 \%$ & $100 \%$ \\
\hline & 70 & 1 & 62 & 35 & 23 & 77 & 47 & 315 \\
\hline \multirow{2}{*}{ WD } & $26.60 \%$ & $3.80 \%$ & $18.80 \%$ & $6.60 \%$ & $0.60 \%$ & $30.00 \%$ & $13.62 \%$ & $100 \%$ \\
\hline & 205 & 29 & 145 & 51 & 5 & 231 & 105 & 771 \\
\hline \multirow{2}{*}{ Total counts } & $25.30 \%$ & $2.80 \%$ & $19.10 \%$ & $7.90 \%$ & $2.60 \%$ & $28.40 \%$ & $14.00 \%$ & $100 \%$ \\
\hline & 275 & 30 & 207 & 86 & 28 & 308 & 152 & 1086 \\
\hline \multicolumn{9}{|c|}{ SCOTLAND } \\
\hline & AUT1 & MOR1 & NAR1 & NOR1 & PAT1 & RAT1 & $\begin{array}{c}\text { Total delegitimation } \\
\text { strategies }\end{array}$ & Total counts \\
\hline \multirow{2}{*}{ SF } & $25.30 \%$ & $2.00 \%$ & $22.00 \%$ & $6.00 \%$ & $2.30 \%$ & $22.00 \%$ & $20.29 \%$ & $100 \%$ \\
\hline & 173 & 14 & 151 & 41 & 16 & 151 & 139 & 685 \\
\hline \multirow{2}{*}{ SD } & $22.40 \%$ & $2.90 \%$ & $23.30 \%$ & $6.30 \%$ & $0.90 \%$ & $22.90 \%$ & $21.35 \%$ & $100 \%$ \\
\hline & 149 & 19 & 155 & 42 & 6 & 152 & 142 & 665 \\
\hline \multirow{2}{*}{ Total counts } & $23.90 \%$ & $2.40 \%$ & $22.70 \%$ & $6.10 \%$ & $1.60 \%$ & $22.40 \%$ & $20.81 \%$ & $100 \%$ \\
\hline & 322 & 33 & 306 & 83 & 22 & 303 & 281 & 1350 \\
\hline
\end{tabular}


Table 4- Legitimation Strategies by Area of Accounting Change in Westminster

\begin{tabular}{|c|c|c|c|c|c|c|c|c|}
\hline Strategy $\rightarrow$ & & & & & & & & Counts \\
\hline \multirow[t]{2}{*}{ Area of accounting change $\downarrow$} & AUT1 & MOR1 & NAR1 & NOR1 & PAT1 & RAT1 & $\begin{array}{c}\text { Total } \\
\text { delegitimation } \\
\text { strategies }\end{array}$ & $\%$ \\
\hline & \multicolumn{8}{|c|}{ HMT } \\
\hline \multirow{2}{*}{ Financial Accounting } & $22.60 \%$ & $0.40 \%$ & $18.80 \%$ & $12.00 \%$ & $7.70 \%$ & $24.80 \%$ & $13.68 \%$ & $100 \%$ \\
\hline & 53 & 1 & 44 & 28 & 18 & 58 & 32 & 234 \\
\hline \multirow{2}{*}{ Budgeting } & $23.10 \%$ & $0.00 \%$ & $17.50 \%$ & $7.00 \%$ & $9.80 \%$ & $28.70 \%$ & $13.99 \%$ & $100 \%$ \\
\hline & 33 & 0 & 25 & 10 & 14 & 41 & 20 & 143 \\
\hline \multirow{2}{*}{ Performance Management } & $13.30 \%$ & $0.00 \%$ & $33.30 \%$ & $0.00 \%$ & $0.00 \%$ & $33.30 \%$ & $20.00 \%$ & $100 \%$ \\
\hline & 2 & 0 & 5 & 0 & 0 & 5 & 3 & 15 \\
\hline \multirow{2}{*}{ Whole Reform } & $22.60 \%$ & $0.00 \%$ & $19.40 \%$ & $11.30 \%$ & $8.10 \%$ & $21.00 \%$ & $17.74 \%$ & $100 \%$ \\
\hline & 14 & 0 & 12 & 7 & 5 & 13 & 11 & 62 \\
\hline HMT & $22.50 \%$ & $0.20 \%$ & $18.90 \%$ & $9.90 \%$ & $8.10 \%$ & $25.80 \%$ & $14.54 \%$ & $100 \%$ \\
\hline Overall count & 102 & 1 & 86 & 45 & 37 & 117 & 66 & 454 \\
\hline Area of accounting change $\downarrow$ & \multicolumn{8}{|c|}{ WD } \\
\hline \multirow{2}{*}{ Financial Accounting } & $25.82 \%$ & $2.29 \%$ & $16.01 \%$ & $12.42 \%$ & $0.33 \%$ & $28.10 \%$ & $15.03 \%$ & $100 \%$ \\
\hline & 79 & 7 & 49 & 38 & 1 & 86 & 46 & 306 \\
\hline \multirow{2}{*}{ Budgeting } & $19.41 \%$ & $0.33 \%$ & $21.38 \%$ & $6.58 \%$ & $4.93 \%$ & $33.55 \%$ & $13.82 \%$ & $100 \%$ \\
\hline & 59 & 1 & 65 & 20 & 15 & 102 & 42 & 304 \\
\hline \multirow{2}{*}{ Performance Management } & $26.98 \%$ & $4.65 \%$ & $24.19 \%$ & $3.72 \%$ & $0.47 \%$ & $27.91 \%$ & $12.09 \%$ & $100 \%$ \\
\hline & 58 & 10 & 52 & 8 & 1 & 60 & 26 & 215 \\
\hline \multirow{2}{*}{ Whole Reform } & $32.61 \%$ & $7.25 \%$ & $15.22 \%$ & $5.07 \%$ & $0.00 \%$ & $28.99 \%$ & $10.87 \%$ & $100.00 \%$ \\
\hline & 45 & 10 & 21 & 7 & 0 & 40 & 15 & 138 \\
\hline WD & $25.03 \%$ & $2.91 \%$ & $19.42 \%$ & $7.58 \%$ & $1.77 \%$ & $29.91 \%$ & $13.40 \%$ & $100 \%$ \\
\hline Overall count & 241 & 28 & 187 & 73 & 17 & 288 & 129 & 963 \\
\hline
\end{tabular}


Table 5 - Legitimation Strategies by Area of Accounting Change in Scotland

\begin{tabular}{|c|c|c|c|c|c|c|c|c|}
\hline Strategy $\rightarrow$ & \multirow{2}{*}{ AUT1 } & \multirow{2}{*}{ MOR1 } & \multirow{2}{*}{ NAR1 } & \multirow{2}{*}{ NOR1 } & \multirow{2}{*}{ PAT1 } & \multirow{2}{*}{ RAT1 } & \multirow{2}{*}{$\begin{array}{c}\text { Total delegitimation } \\
\text { strategies }\end{array}$} & \multirow{2}{*}{$\frac{\text { Counts }}{\%}$} \\
\hline \multirow{2}{*}{ Area of accounting change $\downarrow$} & & & & & & & & \\
\hline & \multicolumn{7}{|c|}{ Scottish Finance } & (n) \\
\hline \multirow{2}{*}{ Financial Accounting } & $22.90 \%$ & $1.80 \%$ & $24.40 \%$ & $10.30 \%$ & $2.60 \%$ & $20.30 \%$ & $17.71 \%$ & $100 \%$ \\
\hline & 62 & 5 & 66 & 28 & 7 & 55 & 48 & 271 \\
\hline \multirow{2}{*}{ Budgeting } & $21.40 \%$ & $2.10 \%$ & $22.30 \%$ & $6.50 \%$ & $1.80 \%$ & $24.40 \%$ & $21.43 \%$ & $100 \%$ \\
\hline & 72 & 7 & 75 & 22 & 6 & 82 & 72 & 336 \\
\hline \multirow{2}{*}{ Performance Management } & $29.20 \%$ & $5.30 \%$ & $22.80 \%$ & $1.80 \%$ & $1.80 \%$ & $24.00 \%$ & $15.20 \%$ & $100 \%$ \\
\hline & 50 & 9 & 39 & 3 & 3 & 41 & 26 & 171 \\
\hline \multirow{2}{*}{ Whole Reform } & $24.60 \%$ & $1.50 \%$ & $18.50 \%$ & $6.20 \%$ & $6.20 \%$ & $16.90 \%$ & $26.15 \%$ & $100 \%$ \\
\hline & 16 & 1 & 12 & 4 & 4 & 11 & 17 & 65 \\
\hline SF & $23.70 \%$ & $2.60 \%$ & $22.80 \%$ & $6.80 \%$ & $2.40 \%$ & $22.40 \%$ & $19.34 \%$ & $100 \%$ \\
\hline Overall count & 200 & 22 & 192 & 57 & 20 & 189 & 163 & 843 \\
\hline Area of accounting change $\downarrow$ & \multicolumn{8}{|c|}{ SD } \\
\hline \multirow{2}{*}{ Financial Accounting } & $18.14 \%$ & $1.33 \%$ & $23.89 \%$ & $11.95 \%$ & $0.00 \%$ & $18.14 \%$ & $26.55 \%$ & $100 \%$ \\
\hline & 41 & 3 & 54 & 27 & 0 & 41 & 60 & 226 \\
\hline \multirow{2}{*}{ Budgeting } & $21.66 \%$ & $1.87 \%$ & $26.20 \%$ & $6.95 \%$ & $0.27 \%$ & $22.46 \%$ & $20.59 \%$ & $100 \%$ \\
\hline & 81 & 7 & 98 & 26 & 1 & 84 & 77 & 374 \\
\hline \multirow{2}{*}{ Performance Management } & $26.42 \%$ & $6.22 \%$ & $22.80 \%$ & $0.52 \%$ & $0.52 \%$ & $25.91 \%$ & $17.62 \%$ & $100 \%$ \\
\hline & 51 & 12 & 44 & 1 & 1 & 50 & 34 & 193 \\
\hline \multirow{2}{*}{ Whole Reform } & $23.40 \%$ & $2.13 \%$ & $14.89 \%$ & $17.02 \%$ & $8.51 \%$ & $19.15 \%$ & $14.89 \%$ & $100 \%$ \\
\hline & 11 & 1 & 7 & 8 & 4 & 9 & 7 & 47 \\
\hline SD & $21.90 \%$ & $2.74 \%$ & $24.17 \%$ & $7.38 \%$ & $0.71 \%$ & $21.90 \%$ & $21.19 \%$ & $100 \%$ \\
\hline Overall count & 184 & 23 & 203 & 62 & 6 & 184 & 178 & 840 \\
\hline
\end{tabular}


i A key aspect of the paper explores how legitimation and voice processes operate at different government levels within the same state. Since 1999 in the UK there have been devolved administrations with devolved powers in Northern Ireland, Scotland and Wales, with these countries remaining part of UK, while ultimate power was retained by Westminster. The term 'Westminster' refers to the UK central government, and reference is often made to Westminster ministers (UK central government ministers) and the Westminster parliament (the UK central parliament). This term comes from the Palace of Westminster, the seat of the UK parliament. The Palace of Westminster is the meeting place of the House of Commons and the House of Lords, the two houses of the parliament of the UK, commonly known as the Houses of Parliament. The comparative empirical aspect of the paper focuses on Westminster (the central UK authority) and one of the devolved administrations, Scotland, this being the largest devolved government body in the UK, with the biggest population and most significant budget.

ii Although beyond the scope of this paper, it should be noted that voice processes during change, their content and direction, are strongly shaped and influenced by the position and power that the actors hold.

iii While previous literature has mainly focused on the positive aspects of voicing one's opinions and/or concerns within an organisation, it is important to recognise that expressing such voice entails a risk for the speaker and the result of voice processes do not necessarily lead to improved conditions for either the speaker or the organisation. We thank one of the reviewers for highlighting this.

iv We thank one of the reviewers for this insightful comment.

$\checkmark$ The selection of the two operational departments was aimed at strengthening variety in the activities and accounting techniques within, and across, each organisation (providing maximum variation as a sampling criterion - see Patton, 2002). Following Brown and Potoski's (2003) classification of public services (in terms of measurability of their output), two departments with significantly varying degrees of measurability were chosen. Rural development was considered as having relatively greater ease of measurability of output (with many of its outputs being freely traded on commercial markets), whereas higher education outputs are generally viewed as less commercial and more difficult to measure and compare in a meaningful (and agreed) manner.

${ }^{\text {vi }}$ It is acknowledged that some of the older changes outlined in Figure 1 (such as the Financial Management Initiative) were unlikely to have been 'lived-through' by the majority of the interviewees. However, it was apparent from the interviews that knowledge of them, and their historical significance relating to change (or signalling change), was appreciated by many of the interviewees.

vii Although beyond the scope of this paper, we acknowledge that the voice process can be seen as a loop of actions and reactions between different departments, both horizontally and vertically. For the purpose of this paper, we analyse the vertical and horizontal dimensions of voice singularly, leaving a more systematic study of any 'looping' to future research.

viii It should be noted (as was highlighted by one of the reviewers of this paper) that FIAG had a wide-ranging membership from Scottish public life and was largely perceived as a group that wished devolution to succeed. Possibly as a consequence of this, it was unanimous in aligning with HMT's accounting and budgeting requirements. While a full consideration of this is beyond the scope of this paper, it should be noted that it is possible that an interviewee from 2014/2015 (who had not 'lived through' the changes or had an incomplete understanding of their history) might consider such changes as imposed. Another view (and one held by the reviewer) is that the FIAG believed that alignment with HMT rules would enlarge the scope for budgetary innovation and lead to a more relevant Scottish parliament with an enhanced devolved policy discretion. A view widely expressed was that there was a significant political will for devolution, particularly because Scotland consistently voted for a Labour government and often ended up with a Conservative government (resulting in a democratic deficit). These issues are discussed in greater length in Midwinter (2000) and Keating (2005).

ix It has been suggested that over this time there has been a progressive movement away from traditional Public Administration systems and accounting tools within the UK public sector, in favour of New Public Management (NPM)-type accounting tools and ideas inspired by the private sector. For a discussion of the reasons for this, and its possible consequences, see, for example: Guthrie et al. (2005), Pollitt and Bouckaert (2011) and Hyndman and Lapsley (2016).

${ }^{x}$ The combination, interaction and overlapping of different legitimation strategies in the presence of different voice processes was not explored in depth in this study in order to keep the paper focused on the main research question and to a reasonable length. Future research may develop this interesting aspect further. 